DOI: 10.36108/ujees/1202.30.0240

\title{
Assessment of Real Estate Outsourcing Practice of Banks and Telecommunication Companies in Lagos, Nigeria.
}

\author{
Fayomi, I., Oladokun, T.T. and Adedokun, A.R.
}

\begin{abstract}
The purpose of this paper is to examine real estate services that are outsourced in the banking and telecommunication sectors and the procedures adopted in outsourcing in Nigeria with a view to providing information that could help in enhancing corporate real estate practice.

Primary data were collected with the aid of questionnaires from the 27 banks and 6 telecommunication operators (totalling 33) who were assessed through their corporate real estate officers. Total enumeration of the 33 selected business organisations was purposively adopted and the data were analysed using frequency and percentage. The study found that $96.3 \%$ and $83.3 \%$ of banks and Telecommunication companies respectively insourced real estate strategic planning services A total of $(69.7 \%)$ in-sourced client relationship management. Also, the most frequently outsourced services by banking and telecommunication companies were property valuation $(72.7 \%)$, space planning $(54.5 \%)$, facility management $(54.5 \%)$, feasibility studies $(33.3 \%)$, site selection and property leases $(55.5 \%)$ among others. The result also showed that two $(6.05 \%)$ categories of organizations adopted the World Bank procedures for selecting outsourced real estate consultants. Professional Estate Surveyors must be up and doing when services are outsourced to them so as prevent usurpation of responsibility and functions from professionals in the built environment and others competing for works in the estate surveying valuation business domain
\end{abstract}

Keywords: Corporate real estate, Outsourcing, Banking sector, Telecommunication sector.

\section{Introduction}

The need to focus more on core competencies and reduce operating expenses by businesses necessitated the outsourcing of services. In other words, management experts have advocated that businesses should focus more on their core competencies and delegate support functions to external service providers and professionals. This argument is premised on the reasoning that specialists can provide such services in a more cost-effective manner than employing staff in-house [1],[2]. Real estate especially constitutes an important aspect of business operations that could be

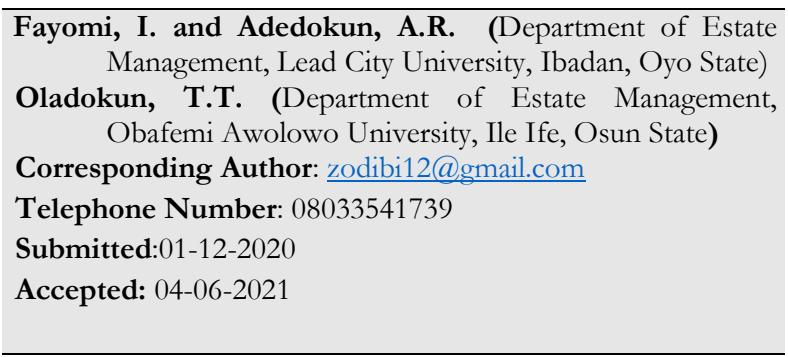

outsourced considering the fact that all businesses whether corporate or individual needs a property either by owning or leasing for its business operation. Buttressing the importance of real estate holding to corporations, [1] posited that all companies require some form of space to house employees, goods and productive processes This suggests that real estate is central and essential to all business activities except few businesses that require little or no space to operate. As such, all organisations always make decisions relating to corporate real estate as it stands as the platform upon which economic activities thrive [2].

The term corporate real estate (CRE) is the real property owned or leased by a business enterprise or organization for achieving its corporate objectives [3]. However, it is important to state that the companies or businesses that own CRE may not be involved in the business of real estate [4]. Corporate real 
estate plays a significant role in the productive process of corporations and its management requires the dedicated services of specialists and professionals who may either function in house or be outsourced.

The term outsourcing is defined as the partial or total contracting of a business task, function, or process to an external service provider for performance [5]. The practise of outsourcing non-core business processes has flourished on a worldwide basis as organizations now seek strategic business advantages in an increasingly competitive market environment [5]. As a concept, outsourcing of real estate services has been used by large organisations to enhance their competitive advantage. Since globalisation has crept into the African market, many organisations such as banks and telecommunication companies, are open to global influences and standards. In addition, the liberalisation of the Nigerian market, which has enhanced the influx of foreign investors into the market, calls for effective management of the real estate of the organisation in line with international standards of outsourcing. The fact that outsourcing seems to be gaining acceptance by corporate organisations, especially banks and telecommunication companies, in African countries such as Nigeria, calls for the need to examine its practice so as to establish the gains that accrue from it to both the stakeholders and the entire banking industry.

Over the last two decades, various research papers have been published across the world emphasizing the importance of CRE and its significance in supporting business processes. Such studies include [6] and [7]. Despite the significance of real estate to corporations and outsourcing in improving efficiency, the services that are outsourced by these corporations were not given adequate research attention. This is in spite of remarkable real estate holdings in these organizations' portfolios. As such, this study investigates services that are outsourced as well as the styles adopted in outsourcing by banking and telecommunication sectors in Lagos, Nigeria because these sectors have grown substantially over the years.

Three stages in the development of outsourcing were identified by [8]. While the first stage (task outsourcing) is aimed at seeking external providers for highly repetitive tasks that only would translate into time and cost savings, the second stage (transactional outsourcing) incorporates the feedback from the service supplier and consequently process refinement and customization. The final stage (integrated outsourcing) incorporates the idea of in-house CRE managers as strategic partners outsourcing certain activities while providing integrated solutions. In the work of [9], two stages in the evolution of outsourcing were also identified. The first stage started in the 1970s when companies began outsourcing CRE services in order to emphasize their core competencies and the second stage emerging during the mid-1990s when companies began searching for advanced partnerships or taking back in-house certain CREM activities due to a renewed emphasis on service quality and to balance quality and costs.

In a bid to understand CRE practice in the financial sector, [7] investigated corporate real estate outsourcing in Poland from the client's perspective. The findings suggest that outsourcing of space planning, moves and valuation is utilized by approximately $50 \%$ of researched CRE managers with portfolio and project management determined as the most unpopular real estate (RE) outsourcing areas. In relation to motivation to outsource, the study found that cost reduction was the key motivator and this was followed by improved service quality and focus on management and strategy. The result further found that improved business flexibility to be the least 
important factor justifying potential real estate outsourcing decisions. This study again was carried out outside Nigeria and was limited to other sectors outside the telecommunication and banking sectors.

In the work of [10], the focus of corporate real estate management outsourcing was carried out in Melbourne, Australia. The study's participants were selected for their experience in issues relating to Corporate Real Estate Management as being in charge of an organization's CRE portfolio, their resultant exposure to outsourcing decision-making, and to represent a range of industry sectors. Although Melbourne organizations surveyed, all were nationally significant and most were organizations with an international presence. Six organizations were investigated, and the findings were considered valid as they represent major Australian CRE organizations representing a range of industry sectors and so may provide results generalized by argument. The study identified six factors that contributed to CREM outsourcing with several organizations reporting multiple contributory factors. The most important factors were cost savings and access to skills, technology and best practice. However, this study may not be applicable in Nigeria as there could exist more than six factors that may influence organizations from outsourcing their corporate real estate assets.

Also, [11] examined corporate real estate management practices in Sweden. The study investigated only those companies listed in the Nasdaq OMX Nordic, the Stockholm Stock Exchange. The findings from the study revealed the following: CREM in Sweden seems to be perceived as a relatively high standing management topic. Today's role of CREM can be described as more functional but a shift towards value management is visible, and CRE in Sweden is mainly focused on functional tasks such as facilitating production and occupancy to cost minimization. Cost also dominates the discussions around CRE performance and information gathered in the portfolios. Sweden is mostly in line with other countries when it comes to activities but more and different information is gathered to analyze CRE performance abroad. This study only focuses on CREM practices leaving out outsourcing aspects of CRE. Also, the findings might not replicate what is happening in the Nigerian context.

Similarly, nine different groups of reasons companies outsource their activities were examined [6]. They are: increasing revenues, business development, organizational reasons, reduces costs, personnel reasons, the need to improve control and reduce risk, only occasional need for particular activities, the need for greater focus on core activities, and too high initial investment for the implementation of certain activities. Most companies frequently outsource to focus on core business or activities. This reason is followed by outsourcing because of the occasional need for particular activities, which means that they use outsourcing to supplement their own resources. However, investments that are capital intensive were not a very important reason to outsource, especially because the survey was done among small and medium-sized companies. It can only mean two things. First, they have good access to financial resources, and secondly, the implementation of individual activities does not require significant investments.

An examination of the outsourcing of corporate real estate asset management was also carried out in New Zealand [12]. The study was the first in New Zealand to examine current practice, emergent trends, and identify outsourcing issues and problems in detail by examining 457 organizations. The work also looked into the reasons behind the trend in outsourcing, the types of services outsourced, 
the basis of selection of service providers, the skills and attributes required of real estate professionals and the success or otherwise of outsourcing experiences in New Zealand. The study found out that the organizations primarily outsource real estate functions to access skills, technology and best practices not available within the organization and because real estate is not their core business. The study further reported that outsourcing has increased significantly over the last five years both in overall frequency and the range of functions covered and this trend is expected to continue, the majority of organizations now have at least an informal outsourcing strategy irrespective of the ownership structure or core business of the organization, organizations with larger property portfolios are more likely to be actively pursuing an outsourcing strategy, as are those with good management information systems, a strategic plan for corporate real estate and a separate corporate real estate management unit. Also, property valuations are clearly the most frequently outsourced service followed by building design, fit out and Resource Management Act expertise according to the research. This study was conducted outside the shore of Nigeria and the findings may not be said to be applicable in Nigeria.

Columbia University survey of CoreNet Global member corporate real estate professionals discovered that transaction management, project management, facilities management, and space planning/moves and changes are most often outsourced. The study also reported that more than one-fourth $(27 \%)$ are expected to increase their outsourcing of project management and $22 \%$ facilities management in the future year. The highest priority in deciding to outsource was to increase shareholder value (by reducing expense), cited as a high priority by $83 \%$ of respondents, followed by cost reduction $(76 \%)$, focus on core competency (64\%) and improved service quality (59\%). A large majority $(80 \%)$ of those who had outsourced real estate functions had achieved at least the cost reduction they had expected and $83 \%$ had experienced significant improvement in quality service at or above expectations. However, the only limitation of this study is that it was conducted outside the shores of Nigeria and the findings cannot be said to be applicable in Nigeria. A more recent study was conducted by [13] on the factors that could influence the outsourcing of corporate real estate functions in Banking and Telecommunications within the Nigerian economy.

The five most mutual factors influencing both sectors were cost control, efficiency, access to skills, technology and best practices, competitive reasons and increased internal productivity, in order of importance. Moreover, adopting a principal component analysis further for the study, it posited that the most important drivers of outsourcing of corporate real estate in the banking and telecommunication sectors were the cost and risk factor, business and technological factor, flexibility factor and the time and value factor. However, it was shown that there is a slight variance from both sectors. For instance, the most important factors influencing corporate real estate outsourcing in the banking industry in order of relevance are cost control, efficiency, access to skills, technology and best practices, competitive reasons and freeing up internal productivity. While in the Telecommunications domain, it was discovered that peace of mind, efficiency, time compression, increasing revenue, competitive reasons, access to skills, technology and best practices, business process re-engineering, value chain analysis, flexibility and increased internal productivity were the most important factors. The study concludes by positing that a relationship that minimizes cost and risk and 
embraces contemporary business and technological inputs in corporate real estate outsourcing, is capable of enhancing the practice and suggests that outsourcing of corporate real estate can be influenced by the characteristics of an organization.

\section{Materials and Methods}

The study population is all the commercial banks, merchant banks, non-interest banks and the major Global System for Mobile Communication (GSM) organization in Nigeria. Moreover, these sectors have their head offices located in Lagos State, their corporate real estate executives were targeted for questionnaire administration. The sample frame adopted for this study consists of all the 22 commercial banks, 4 merchant banks, 1 non-interest bank and the 6 major Global System for Mobile Communication (GSM) organizations in Lagos, Nigeria totaling 33. Total enumeration of the 33 identified samples was adopted. Questionnaires were adopted for data collection. This was considered the most appropriate because the respondents were learned and educated. Information solicited included general real estate operations that corporate organizations cannot most of the time do without with respect to their corporate properties and they include property management and building operations, maintenance and repairs, acquisition, leasing and development, Space planning/moves, valuation services, facility management services, portfolio management services, transaction management services, project management services. A total of 33 questionnaires were administered at the head offices of the operators and all were retrieved due to persistent requests and demand to complete the questionnaire by the researchers using the purposive sampling technique. The data were analysed using frequency and percentage.

\section{Results and Discussion}

Before presenting major findings on CRE outsourcing practice in both sectors, an attempt is made to analyze the overall profile of the commercial banks, merchant banks, non-interest banks and telecommunication companies, the ownership structure of the individual banks and telecommunication companies were examined. Furthermore, the organization's staff strength, the nature of their businesses, means of handling real estate costs, their cost handling techniques, and real estate unit structure were examined. The result revealed that most of the banks were publicly listed which amounted to $88.9 \%$ while three (3) of the sampled banks were privately owned representing $11.1 \%$. In the same vein, two (2) of the telecommunication companies representing $33.3 \%$ were publicly owned while four (4) which is $66.7 \%$ of the telecommunication companies were privately owned. Hence, putting together the organizations in the banking and telecommunication sector, twenty-six (26) of the organizations were publicly owned while only seven (7) were privately owned. This might be due to the large capital required in the establishment of both organizations if attempted by private corporate organisations. Table 1, explains the structure of the real estate unit present in both the banking and the telecommunication sectors. As revealed, $85.2 \%$ of the banks attest that there is the presence of an organized real estate unit or persons incharge of the real estate unit in their organization while only $14.8 \%$ of the banks do not have an organized real estate unit. Furthermore, $66.7 \%$ of telecommunication companies have an organized real estate unit while only $33.3 \%$ of these companies do not have an organized real estate unit. 
Table 1: Presence of Formally Organized Real Estate Units

\begin{tabular}{llll}
\hline $\begin{array}{l}\text { Formally } \\
\text { Organized } \\
\begin{array}{l}\text { Real Estate } \\
\text { Unit }\end{array}\end{array}$ & Banking & Telecommunication & \\
\hline Present & 23 & $4(66.7 \%)$ & Total \\
& $(85.2 \%)$ & & $\mathbf{2 7}$ \\
& 4 & $2(33.3 \%)$ & $\mathbf{6} \%)$ \\
Not & $4.8 \%)$ & & $\mathbf{( 1 8 . 2 \% )}$ \\
Present & $(14.8 \%)$ & $\mathbf{3 3}$ \\
Total & $\begin{array}{l}\mathbf{2 7} \\
(\mathbf{1 0 0 . 0 \% )}\end{array}$ & $\mathbf{6 ( 1 0 0 . 0 \% )}$ & $\mathbf{( 1 0 0 . 0 \% )}$ \\
& & & \\
\hline
\end{tabular}

Source: Authors Field Survey (2019)

Although in both sectors, a majority $(81.8 \%)$ of the organizations each has a structured real estate unit, it was established in the result of the analysis that this act is more conversant with the banking sector. This might be due to the fact that the banking and real estate sectors work in line and both sectors require the services of each other, for instance in terms of land acquisition, valuation and forced sales to mention a few.

Ascertaining the presence of organized real estate units in each of the sectors, $81.5 \%$ of the banks had property management staff ranging from 1 to 10 which represent the highest percentage. However, in the telecommunication sector, $83.3 \%$ of the telecommunication companies had between 1 and 10 property management staff. This implies that, in both sectors, the number of management staff employed in each organization is between 1 and 10 .

The result further revealed that in both sectors real estate management was not a separate business unit earning a return on the capital tied up in real estate assets by providing the space requirements of operating units in return for market-related rents and operating expenses. Although $25.9 \%$ of the banks in the banking sector asserted that the role of real estate management in banks was to examine trends in conjunction with operating units, developing the real estate implications of these trends and proposing optimal solutions which were not so with the telecommunication sector.

Therefore, in examining the corporate real estate services that are outsourced in the banking sector and the telecommunication sector, Twenty-one (21) corporate real estate services were identified and placed to be examined by the respondents' in both sectors. The result is presented in Table 2.

The result, as contained in Table 2, reveals that majority of the banks and telecommunication companies operate real estate strategic planning services in their organizations using in-sourcing. This accounted for $96.3 \%$ and $83.3 \%$ respectively while only $3.7 \%$ of banks and $16.7 \%$ of the telecommunication companies outsourced this service. The prevalence of the adoption of insourcing in both sectors could be because planning services is seen as a driver towards achieving the organized goals; a service that needs to be painstakingly undertaken by top management. This finding is in contrast to [2] that planning and decision service was procured using outsourcing in Nigeria.

Also, client relationship management service was majorly procured using in-sourcing in both banking and telecommunication sectors as adopted by $66.7 \%$ and $83.3 \%$ of the organisations respectively while $6.1 \%$ of the organisations procured this service using the hybrid style. This result is however expected because most organizations especially in the banking sector have client relations officers who oversee this aspect of their organizations. This also suggests that organizations preferred to monitor this service closely as it is a colossus in client's retention.

The study further found that acquisition, leasing and development services were outsourced by $(55.6 \%)$ of the banks and 
$(50.0 \%)$ of those in the telecommunication sectors. Also, on the outsourcing style adopted, the result showed that $25.9 \%$ of the banks use the hybrid style while $18.5 \%$ of them procured services such as acquisition, leasing and development services using the in-sourcing style. Again, $33.3 \%$ of the telecommunication companies used in-sourcing style for this service while $16.7 \%$ of them carry out the service using the hybrid style. Overall, the result showed that $54.5 \%$ of organisations in the two sectors used the outsourcing style for acquisition, leasing and development services. This result could be attributed to the fact that this particular service is outside the scope of both sectors and for it to be adequately carried out there is a need to employ the services of professionals like Estate Surveyors and Valuers' for expertise and value creation.

Table 2: Mode of Procuring Real Estate Services by Banking and Telecommunication Operators

\begin{tabular}{|c|c|c|c|c|}
\hline CRE Services & CRE Styles & Banks (\%) & Telecommunication (\%) & Total (\%) \\
\hline \multirow[t]{4}{*}{ Real estate strategic Planning } & In-sourcing & $26(96.3)$ & $5(83.3)$ & $31(93.9)$ \\
\hline & Outsourcing & $1(3.7)$ & $1(16.7)$ & $2(6.1)$ \\
\hline & Hybrid & --- $(0.0)$ & --- $(0.0)$ & $---(0.0)$ \\
\hline & Total & $27(100.0)$ & $6(100.0)$ & $33(100.0)$ \\
\hline \multirow{4}{*}{ Client relationship management } & In-sourcing & $18(66.7)$ & $5(83.3)$ & $23(69.7)$ \\
\hline & Outsourcing & $7(25.9)$ & $1(16.7)$ & $8(24.2)$ \\
\hline & Hybrid & $2(7.4)$ & $---(0.0)$ & $2(6.1)$ \\
\hline & Total & $27(100.0)$ & $6(100.0)$ & $33(100.0)$ \\
\hline \multirow{4}{*}{$\begin{array}{l}\text { acquisition, leasing and } \\
\text { development }\end{array}$} & In-sourcing & $5(18.5)$ & $2(33.3)$ & $8(24.2)$ \\
\hline & Outsourcing & $15(55.6)$ & $3(50.0)$ & $18(54.5)$ \\
\hline & Hybrid & $7(25.9)$ & $1(16.7)$ & $7(21.2)$ \\
\hline & Total & $27(100.0)$ & $6(100.0)$ & $33(100.0)$ \\
\hline \multirow[t]{4}{*}{ Portfolio management services } & In-sourcing & $6(22.2)$ & $--(0.0)$ & $6(18.2)$ \\
\hline & Outsourcing & $20(74.1)$ & $6(100.0)$ & $26(78.8)$ \\
\hline & Hybrid & $1(3.7)$ & $---(0.0)$ & $1(3.0)$ \\
\hline & Total & $27(100.0)$ & $6(100.0)$ & $33(100.0)$ \\
\hline \multirow[t]{4}{*}{ Financial analysis } & In-sourcing & $10(37.0)$ & $3(50.0)$ & $13(39.4)$ \\
\hline & Outsourcing & $8(29.6)$ & $2(33.3)$ & $10(30.3)$ \\
\hline & Hybrid & $9(33.3)$ & $1(16.7)$ & $10(30.3)$ \\
\hline & Total & $27(100.0)$ & $6(100.0)$ & $33(100.0)$ \\
\hline \multirow[t]{4}{*}{ Facility management services } & In-sourcing & $10(37.0)$ & $1(16.7)$ & $11(33.3)$ \\
\hline & Outsourcing & $14(51.9)$ & $4(66.7)$ & $18(54.5)$ \\
\hline & Hybrid & $3(11.1)$ & $1(16.7)$ & $4(12.1)$ \\
\hline & Total & $27(100.0)$ & $6(100.0)$ & $33(100.0)$ \\
\hline \multirow{4}{*}{$\begin{array}{l}\text { Property management and } \\
\text { building operations }\end{array}$} & In-sourcing & $6(22.2)$ & $--(0.0)$ & $6(18.2)$ \\
\hline & Outsourcing & $11(40.7)$ & $5(83.3)$ & $16(48.5)$ \\
\hline & Hybrid & $10(37.0)$ & $1(16.7)$ & 11(33.3) \\
\hline & Total & $27(100.0)$ & $6(100.0)$ & $33(100.0)$ \\
\hline \multirow[t]{4}{*}{ Maintenance and repairs } & In-sourcing & $2(7.4)$ & --- $(0.0)$ & $2(6.1)$ \\
\hline & Outsourcing & $17(63.0)$ & $4(66.7)$ & $21(63.6)$ \\
\hline & Hybrid & $8(29.6)$ & $2(33.3)$ & $10(30.3)$ \\
\hline & Total & $27(100.0)$ & $6(100.0)$ & $33(100.0)$ \\
\hline \multirow[t]{4}{*}{ Valuation services } & In-sourcing & $4(14.8)$ & --- $(0.0)$ & $4(12.1)$ \\
\hline & Outsourcing & $19(70.4)$ & $5(83.3)$ & $24(72.7)$ \\
\hline & Hybrid & $4(14.8)$ & $1(16.7)$ & $5(15.2)$ \\
\hline & Total & $27(100.0)$ & $6(100.0)$ & $33(100.0)$ \\
\hline \multirow[t]{4}{*}{ Space planning/moves } & In-sourcing & $9(33.3)$ & $1(16.7)$ & $10(30.3)$ \\
\hline & Outsourcing & $13(48.1)$ & $5(83.3)$ & $18(54.5)$ \\
\hline & Hybrid & $5(18.5)$ & $---(0.0)$ & $5(15.2)$ \\
\hline & Total & $27(100.0)$ & $6(100.0)$ & $33(100.0)$ \\
\hline \multirow{3}{*}{$\begin{array}{l}\text { Property/lease administration } \\
\text { services }\end{array}$} & In-sourcing & $1(3.7)$ & $1(16.7)$ & $2(6.1)$ \\
\hline & Outsourcing & $14(51.9)$ & $3(50.0)$ & $17(51.5)$ \\
\hline & Hybrid & $12(44.4)$ & $2(33.3)$ & $14(42.4)$ \\
\hline
\end{tabular}




\begin{tabular}{|c|c|c|c|c|}
\hline \multirow{5}{*}{ Project management services } & Total & $27(100.0)$ & $6(100.0)$ & $33(100.0)$ \\
\hline & In-sourcing & $12(44.4)$ & $4(66.7)$ & $16(48.5)$ \\
\hline & Outsourcing & $7(25.9)$ & $---(0.0)$ & $7(21.2)$ \\
\hline & Hybrid & $8(29.6)$ & $2(33.3)$ & $10(30.3)$ \\
\hline & Total & $27(100.0)$ & $6(100.0)$ & $33(100.0)$ \\
\hline \multirow{4}{*}{$\begin{array}{l}\text { Feasibility study / market } \\
\text { analysis }\end{array}$} & In-sourcing & $6(22.2)$ & $---(0.0)$ & $6(18.2)$ \\
\hline & Outsourcing & $13(48.1)$ & $4(66.7)$ & 17 (51.5) \\
\hline & Hybrid & $8(29.6)$ & $2(33.3)$ & $10(30.3)$ \\
\hline & Total & $27(100.0)$ & $6(100.0)$ & $33(100.0)$ \\
\hline \multirow[t]{4}{*}{ Selection of sites/premises } & In-sourcing & $4(14.8)$ & $---(0.0)$ & $4(12.1)$ \\
\hline & Outsourcing & $23(85.2)$ & $6(100.0)$ & $29(87.9)$ \\
\hline & Hybrid & $---(0.0)$ & --- $(0.0)$ & --- $(0.0)$ \\
\hline & Total & $27(100.0)$ & $6(100.0)$ & $33(100.0)$ \\
\hline \multirow[t]{4}{*}{ Procurement of sites/premises } & In-sourcing & $20(74.1)$ & $6(100.0)$ & $26(78.8)$ \\
\hline & Outsourcing & $4(14.8)$ & $---(0.0)$ & $4(12.1)$ \\
\hline & Hybrid & $3(11.1)$ & $---(0.0)$ & $3(9.1)$ \\
\hline & Total & $27(100.0)$ & $6(100.0)$ & $33(100.0)$ \\
\hline \multirow[t]{4}{*}{ Space layout planning } & In-sourcing & $2(7.4)$ & --- $(0.0)$ & $2(6.1)$ \\
\hline & Outsourcing & $22(81.5)$ & $6(100.0)$ & $28(84.8)$ \\
\hline & Hybrid & $3(11.1)$ & --- $(0.0)$ & $3(9.1)$ \\
\hline & Total & $27(100.0)$ & $6(100.0)$ & $33(100.0)$ \\
\hline \multirow[t]{4}{*}{ Town planning issues } & In-sourcing & $9(33.3)$ & $1(16.7)$ & $10(30.3)$ \\
\hline & Outsourcing & $16(59.3)$ & $5(83.3)$ & $21(63.6)$ \\
\hline & Hybrid & $2(7.4)$ & $---(0.0)$ & $2(6.1)$ \\
\hline & Total & $27(100.0)$ & $6(100.0)$ & $33(100.0)$ \\
\hline \multirow[t]{4}{*}{ Surplus property/lease disposal } & In-sourcing & $5(18.5)$ & $1(16.7)$ & $6(18.2)$ \\
\hline & Outsourcing & $11(40.7)$ & $5(83.3)$ & $16(48.5)$ \\
\hline & Hybrid & $11(40.7)$ & $---(0.0)$ & $11(33.3)$ \\
\hline & Total & $27(100.0)$ & $6(100.0)$ & $33(100.0)$ \\
\hline \multirow[t]{4}{*}{ Brokerage } & In-sourcing & $16(59.3)$ & $3(50.0)$ & $8(24.2)$ \\
\hline & Outsourcing & $5(18.5)$ & $3(50.0)$ & $8(57.6)$ \\
\hline & Hybrid & $6(22.2)$ & --- $(0.0)$ & $6(18.2)$ \\
\hline & Total & $27(100.0)$ & $6(100.0)$ & $33(100.0)$ \\
\hline \multirow[t]{4}{*}{ Environmental engineering } & In-sourcing & $6(22.2)$ & $2(33.3)$ & $8(24.2)$ \\
\hline & Outsourcing & $12(44.4)$ & $4(66.7)$ & $16(48.5)$ \\
\hline & Hybrid & $9(33.3)$ & $---(0.0)$ & $9(27.3)$ \\
\hline & Total & $27(100.0)$ & $6(100.0)$ & $33(100.0)$ \\
\hline \multirow[t]{4}{*}{ Disposition marketing } & In-sourcing & $2(7.4)$ & $2(33.3)$ & $4(12.1)$ \\
\hline & Outsourcing & $9(33.3)$ & $1(16.7)$ & $10(30.3)$ \\
\hline & Hybrid & $16(59.3)$ & $3(50.0)$ & $19(57.6)$ \\
\hline & Total & $27(100.0)$ & $6(100.0)$ & $33(100.0)$ \\
\hline
\end{tabular}

Source: Field Survey (2019)

On portfolio management service, $74.1 \%$ of banks in the study area indicated that the service was outsourced. Again, $22.2 \%$ of them procured this service using in-sourcing while $3.7 \%$ of them used the hybrid style to procure the service. Regarding the telecommunication sector, the study showed that portfolio management services were outsourced. Further, the overall result that pertains to both sectors showed that $78.8 \%$ of them outsourced portfolio management services while $18.2 \%$ of the services were procured using an in-sourcing style. Also, only $3.0 \%$ of them procured these services through a hybrid style. The study further found that property valuation service is the most outsourced corporate real estate service by banking and telecommunication sector in Nigeria as this accounted for almost 
Table 3: Summary of Corporate Real Estate Services Outsourced in Banking and Telecommunication Sector

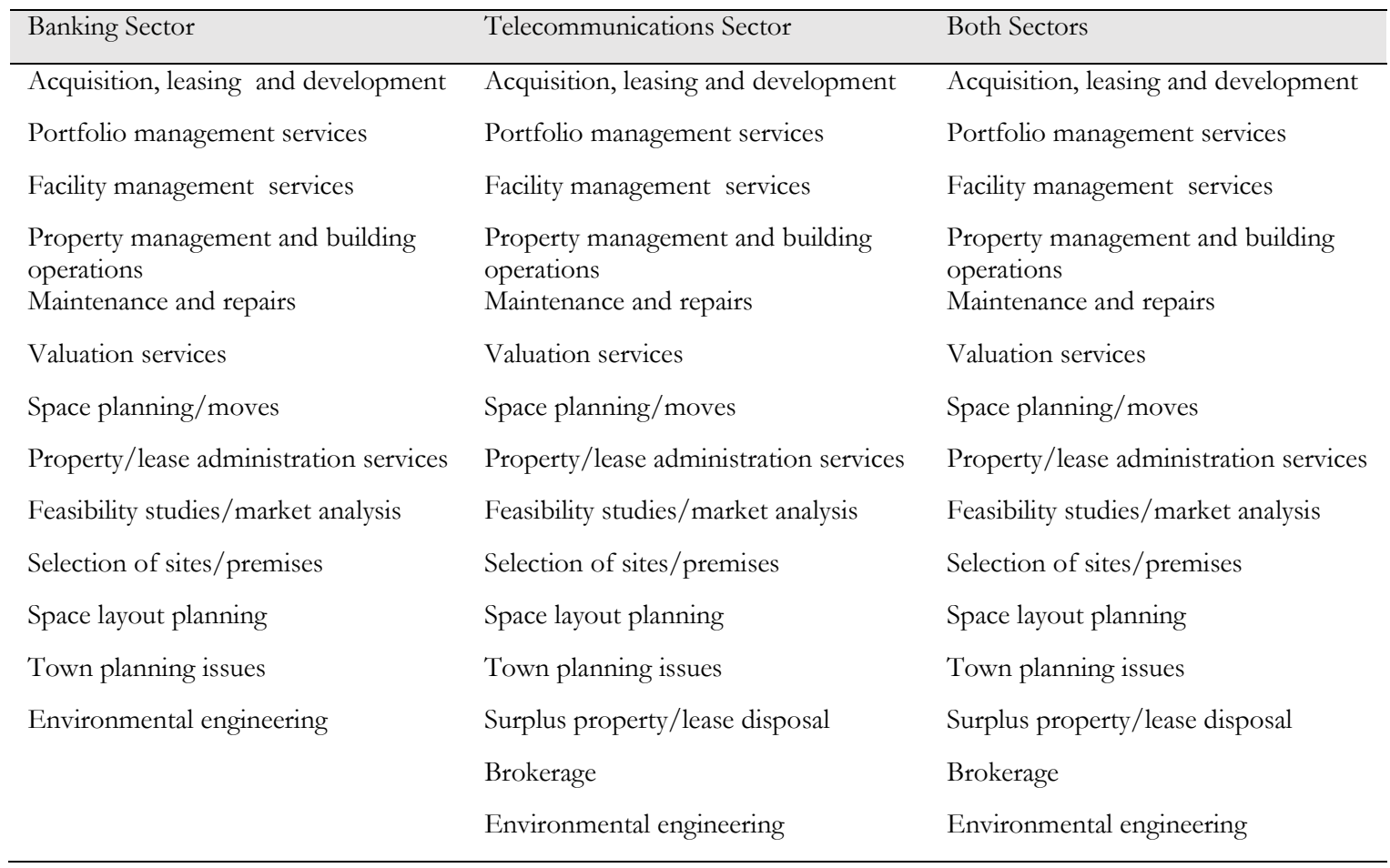

$73 \%$. This confirmed the work as reported in [12] that valuation service was the most frequently outsourced service in New Zealand.

In the same vein, maintenance and repair and facility management services were outsourced frequently by (almost 64\%) of the organizations in the banking and telecommunication sectors in Nigeria. This could be attributed to the fact that the services required specialised knowledge and skill. The findings also showed that space planning was frequently outsourced by $(54.5 \%)$ of companies in both sectors in Nigeria. This result is in tandem with the study of Bocian and Fortune (2010) in Poland that space planning accounted for $50 \%$ of outsourced services.

Implicit in Table 3 is the summary of corporate real estate services outsourced by the banking and telecommunication sector in the study area. A cursory look at the information in Table 3 indicated that acquisition, leasing and development, portfolio management services, facility management services, property management and building operations, maintenance and repairs, valuation services, space planning/moves, property/lease administration services, feasibility studies/market analysis, and selection of sites/premises among others were commonly outsourced services by banking and telecommunication. This could be because these services are outside the core competency of the operators and to attain better service and efficient use of resources, it was being outsourced to an expert.

\section{Conclusion}

The study examined the corporate real estate services that are outsourced in the banking and telecommunication sectors in Nigeria. This was with a view to enhancing the practice in Nigeria. The findings showed that in both sectors, services like acquisition, leasing and development, portfolio management services, facility management services, property 
management and building operations, maintenance and repairs services, valuation services, space planning/moves, property/lease administration services, feasibility studies/market analysis, selection of sites/premises, space layout planning, town planning issues, environmental engineering, brokerage and surplus property/lease disposal were majorly outsourced. The result could be linked to that these services need to be adequately procured, there is a need to employ professionals for value creation so as to improve quality service to the customers. It is therefore imperative for the professionals such as estate surveyors and valuers to update their knowledge, especially in outsourcing best practices so as not to falter in their professional calling as such scenario may have serious implications on the client base and consequently revenue accruable as banks and telecommunication companies concentrate on their core area for enhanced business efficacy. Therefore, Estate Surveyors and Valuers must perform their work professionally and with dexterity in order to win over the trust and confidence of clients.

Although in the banks and telecommunication companies, real estate strategic planning and client relationship management were procured using in-sourcing. This is because this real estate strategic planning gives direction to the businesses so as to achieve vision and goals while client relationship management needs to be provided at close range for proper monitoring of clients. This suggests that the estate surveyors in the paid employment of banking and telecommunication sectors in Nigeria need to provide better and improved services to these organizations as these services are so pertinent to the survival of these organizations. Also, the sector is important to the growth and development of any nation. It, therefore, implies that the professional estate surveyors must be up and doing so as to prevent usurpation of responsibility and function from professionals in the built environment and others competing for works in the estate surveying valuation business domain.

\section{References}

[1] Gibler, K.M. and Black, R.T. "Agency Risks in Outsourcing Corporate Real Estate Functions", Journal of Real Estate Research, vol. 26, no. 2, 2004, pp. 137-160.

[2] Oladokun, T.T. "Corporate Site Selection and Acquisition in a Nigerian GSM Communication Company", Journal of Corporate Real Estate, vol. 13, no. 4, 2011, pp. 247 - 260.

[3] Fayomi, I., Oladokun T.T. and Adewolu T.O. "Factors Influencing Corporate Real Estate Outsourcing In Nigeria: An Empirical Study From The Banking And Telecommunication Sectors In Lagos, Nigeria. Book of Proceedings of the 1st International Conference on Engineering and Environmental Sciences, Osun State University. November 5-7, 2019", Theme: Advancing Technology and Environmental Burdens: Challenges and Sustainable Solutions, 2020, pp. 257-272.

[4] Joroff, M., Louargand, M., Lambert, S. and Becker, F. "Strategic Management of the Fifth Resource: Corporate Real Estate", Industrial Development Research Foundation, Atlanta, 1993

[5] Hayward, T.J. "The Outsourcing of Corporate Real Estate Asset Management in New Zealand", A dissertation submitted at Lincoln University in partial fulfilment of the requirements of the Degree of Master of Property Studies, 1999.

[6] Barbara, B.H. "Correlation between Reasons and Effects of Outsourcing: Evidence from Slovenian SME", Faculty of Economics and Business University of Maribor Maribor, Slovenia, 2010.

[7] Bocian, R. and Fortune, J. "Corporate Real Estate Outsourcing in the Financial Sector in Poland: the client's Perspective", 2010, pp. 70-86. Available from Sheffield Hallam University Research Archive (SHURA) at: http://shura.shu.ac.uk/7581/ accessed March, 2018. 
[8] Jacobs, B., Lickerman, T., Mackenzie, I. and Yearley, P. "Beyond Boundaries - Leveraging Partners to Maximize the Value Chain", Jones Lang LaSalle IP, 2007.

[9] Ilsjan, V. "Corporate Real Estate Management (CREM) in Estonia", Journal of Corporate Real Estate, vol. 9, no. 4, 2007, pp. 257-277.

[10] Matsham, A. and Heywood, C. "An Investigation of Corporate Real Estate Management Outsourcing in Melbourne", Eighteenth Annual Pacific-Rim Real Estate Society Conference Adelaide, Australia, 2012, pp. 15-18.

[11[ Holfert, E. and Villamide, M. "Corporate Real Estate Management Practices in Sweden", 2011.

[12] McDonagh, J. and Hayward, T. (2000). Outsourcing Corporate Real Estate Asset Management in New Zealand", Journal of Corporate Real Estate, vol. 2, no. 4, 2000, 351 - 371.

[13] Brown, K., Arnold, A.L., Rabianski, J.S., Carn, N.G., Lapides, P.D., Blanchard, S.B. and Rondeau, E.P. "Managing Corporate Real Estate, New York: John Wiley", 1993. 